\title{
Learning From the Doers: Developing Country Lessons for Advanced Economy Growth
}

\author{
Anusha Chari and Peter Blair Henry*
}

\begin{abstract}
From 1980 to 1992, emerging and developing countries grew by 3.4 percent per year. Their annual rate of growth increased to 5.4 percent between 1993 and 2012. No such increase occurred for advanced nations, whose average growth from 1980-2012 was roughly constant (excluding the impact of the 2008-09 Recession). Developing nations turned themselves around by embracing discipline-sustained commitment to a pragmatic and flexible growth strategy. Three illustrations of discipline through the lens of trade, fiscal, and debt reforms in the developing world offer relevant, practical lessons for recovery in advanced economies and continued catch-up growth in developing nations.
\end{abstract}


Not long ago, developing and emerging economies were known as "Third World" nations mired in poverty, debt crises, stratospheric inflation rates, and chronic instability while advanced countries seemed to hold the keys to prosperity. Tables have turned. The first decade of the $21^{\text {st }}$ century brought unprecedented economic progress in the developing world, which now produces half of global GDP and is expected to account for almost three quarters of global growth by 2017. It has been a less auspicious time for developed countries, evidenced by the epic Financial Crisis of 2008-09 and its consequences for the United States and Europe.

As the fortunes of nations ebb and flow, it is important to distinguish between cycles and trends. Recent statistics suggesting an upswing in advanced countries and decreased growth in emerging markets divert our attention from the most important story about the world economy since the end of the Second World War, even as it continues to unfold. Namely, that through their struggle to reject failed models of development such as dependency theory and central planning —often at the behest of advanced-nation governments in the past—a critical mass of developing countries turned themselves around by embracing the true key to success: a disciplined approach to economic policy. ${ }^{1}$

Discipline is a sustained commitment to a pragmatic growth strategy executed with a combination of temperance, vigilance, and flexibility that values the long-term prosperity of all over the short-term enrichment of any single group (Henry, 2013). Figure 1, which we constructed using data from the International Monetary Fund's World Economic Outlook (WEO) database and which plots the average growth rate of real GDP in advanced as well as emerging and developing economies from 1980 through 2012, tells the central story that the rest of this

\footnotetext{
${ }^{1}$ For the origins of dependency theory see Prebisch (1950) and Singer (1950).
} 
article develops in some detail. In addition to the well-documented contraction of advanced economies during the Great Recession of 2008-09, the figure presents two salient facts.

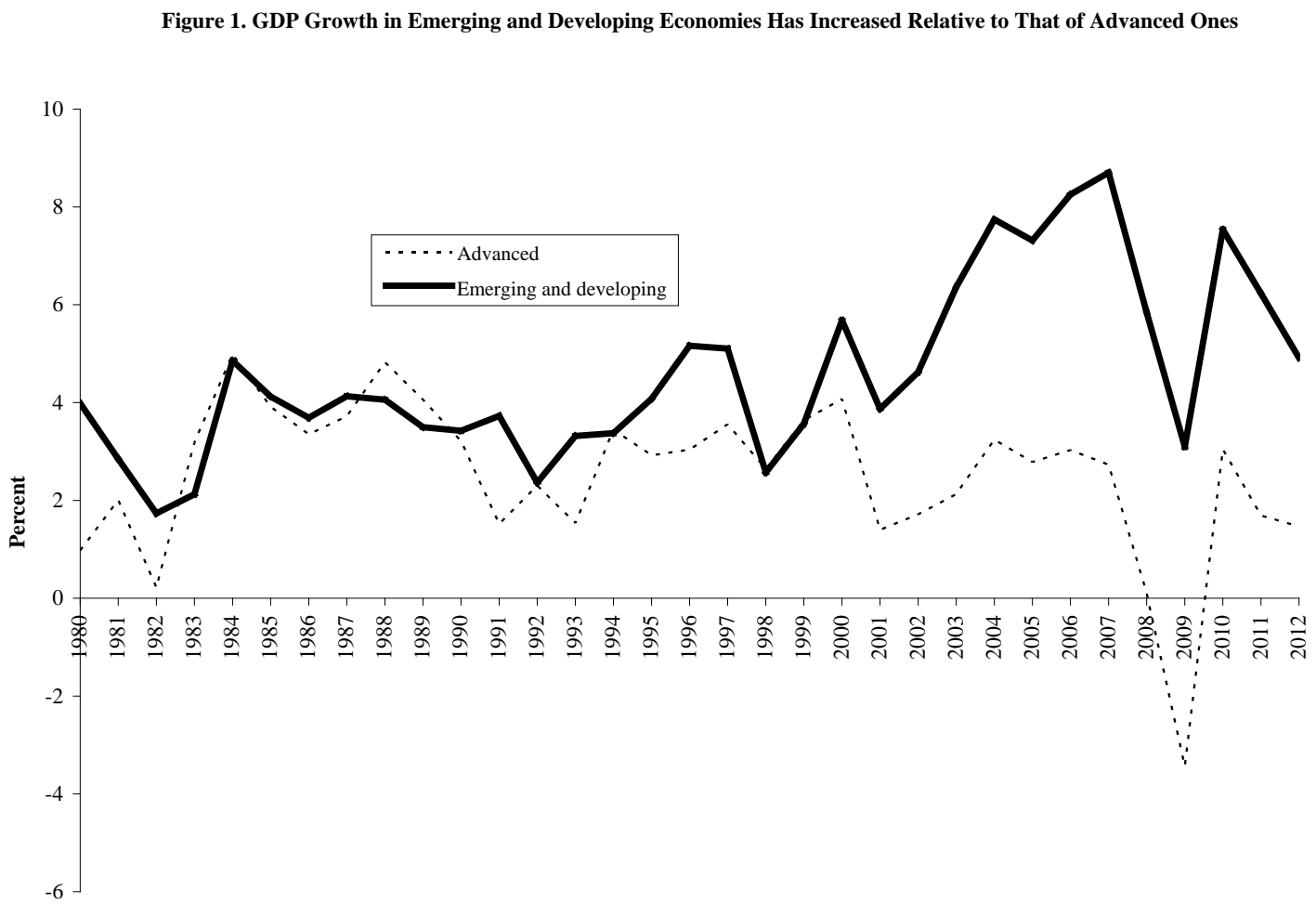

First, the growth rate of real GDP in the developing world has been dramatically higher in the last two decades than it was in the 1980s. Between 1980 and 1992, the average growth rate of real GDP in developing countries was 3.4 percent per year versus 5.4 percent from 1993 to 2012. The significance of this two-percentage-point increase in growth is profound: for a country whose population grows at 1 percent per year, annual GDP growth of 3.4 percent means that per capita income doubles once every 29 years; with 5.4 percent growth, per capita income doubles in just 16.

Second, excluding the years 2007-2012, which was a period of slower growth in developed countries because of the recession—a negative shock that had little to do with developing countries per se-there has been no substantive decline in advanced-country fortunes 
following the acceleration of growth in the developing world. Developed countries grew by 2.9 percent per year from 1980 to 1992 -almost identical to the 2.8 percent rate at which they expanded from 1993 to 2007. There is little if any evidence to support an argument that faster growth in the emerging world came at the expense of average living standards in advanced nations.

The relatively flat line for growth in advanced economies also suggests that the accelerated rise of living standards in developing countries was not caused by an aggregate shock to the global economy, but points to the idiosyncratic set of reforms (e.g., inflation stabilization and trade liberalization) that were adopted during the 1990s as an unprecedented number of countries rejected ideological approaches to economic policymaking and instead embraced discipline. The pages ahead provide specific illustrations of discipline, seen through the lens of economic reform in the developing world—a story of turnaround in three acts, each of which offers practical lessons for welfare-improving outcomes.

\section{The Trade Trap: Discipline Avoids Mercantilism}

The recent slow growth in advanced nations has lured their governments into the mercantilist trap of thinking that exports are good, imports are bad, and a large trade surplus is the key to renewed prosperity. Measured by the number of protectionist measures imposed since November 2008, France, Germany, Italy, and the United Kingdom are all on the list of the world's top 10 most protectionist countries (Evenett, 2013). The opening act of economic reform in the developing world—South Korea's rise from impoverished nation in the 1950s to manufacturing juggernaut—predates the WEO’s time series on global growth, but it demonstrates that discipline in the context of free trade lies not in running surpluses but in 
driving up productivity through a sustained process of easing restrictions on both imports and exports.

In the 1950s, the Cold War occupied center stage, and countries like Singapore and South Korea were far from the economic "tigers" they would become. In keeping with dependency theory, the dominant intellectual paradigm in the developing world at the time, both countries eschewed trade with developed nations in order to pursue a policy of industrialization through import substitution, but the strategy was not successful in either country. As of 1960, South Korea’s GDP per capita was US\$1,100. Evaluating South Korea's prospects for the future at the time, the U.S. Congress argued there was "little or no hope for sustained growth,” while World Bank studies claimed “industrial growth in Korea was not feasible.”2

In 1964, the Korean government confronted the shortcomings of import substitution and began liberalizing trade. The reduction of import restrictions was a key element of Korea’s successful pivot to export-oriented growth. Although policymakers maintained high tariffs on a wide range of imports, they understood that certain capital goods, intermediate inputs, and transportation equipment were vital for production and therefore the country’s economic development. Accordingly, they created a minimal "positive” list of permissible investment goods that they allowed to expand over time. By 1967, the commitment to opening up had grown to the point where policymakers replaced the previous list with a "negative" one-a new protocol under which importers were automatically granted permission for any item not enumerated.

Korea’s import liberalization strategy had at least two positive effects on the economy. First, it reduced the cost of production by providing workers and firms with critical inputs at lower prices. Second, it enabled Korean companies to reverse-engineer everything from

\footnotetext{
${ }^{2}$ Krueger (2010).
} 
automobiles to electronic equipment, effectively importing new technologies that would have taken decades to develop in isolation. Working with government-supported research and development organizations (ranging from the Korean Institute of Machinery and Metals to the Electronics and Telecommunications Research Institute), Korean companies were able to assimilate and improve upon a variety of technologies that helped them leapfrog the learning curve and become world-class firms such as Hyundai and Samsung.

The Korean government unquestionably played a significant role in the country's rise to economic prominence, and critics of economic reform often cite this involvement as evidence that extensive government intervention and industrial policy are viable alternatives to more market-oriented economies. But this critique misses the larger point. The key to Korea's turnaround was not so much an ideological tilt toward a large role for government as it was the discipline to enact and sustain policy changes that empowered firms to take advantage of the international marketplace. For example, the decision in 1964 by Korean policymakers to devalue the won helped drive the success of their import liberalization strategy. By offsetting the impetus for real exchange-rate appreciation created by Korea’s remaining import barriers, the devaluation restored external competitiveness and set the stage for the takeoff of the country's manufacturing sector.

The Korean government's willingness to reject import substitution and embrace trade radically altered the country’s economic trajectory. From 1960 to 2005, Korea’s average standard of living increased twelvefold, with imports and exports working together to drive productivity gains from comparative advantage. Korean exports increased from 4.8 percent of GDP in 1963 to 34 percent in 1980. Over the same period, imports as a fraction of GDP rose from 15.9 percent to 41.4 percent. It bears emphasizing that Korea’s trade balance was negative 
in both 1963 and in 1980. Indeed, between 1965 and 1990, Korea grew by 7.1 percent per year while running persistent trade deficits.

\section{Fiscal Follies: Discipline Does Not Equal Austerity}

From international trade to public finance, the appropriate role of government in economic activity remains a controversial topic. The Great Recession triggered a contentious debate over whether fiscal consolidation (austerity) is helpful or harmful in restoring developed economies to full employment and sustainable debt trajectories. These debates intensified during the U.S. sequestration standoff and deliberations over the European Fiscal Compact.

Economic commentators from both ends of the political spectrum mistakenly conflate discipline with the false courage to implement extreme policies. When it comes to whether to impose fiscal austerity, however, studying the historical (and objective) responses of developingcountry stock markets to implementation of austerity programs demonstrates the error of unyielding views. Thirty years of data from emerging markets suggest that the disciplined course of action depends largely on the prevailing level of inflation in the country at the time austerity is being considered.

The stock market is a useful tool for determining what discipline means in the context of fiscal policy, because it internalizes both the short- and long-run effects of austerity (Henry, 2002). To the extent that austerity creates expectations of slower growth and higher discount rates in the short run, it will depress present values. But the potential of higher growth and lower discount rates in the long run creates an offsetting effect. If the expected long-run benefits outweigh the short-run costs, then the country's stock market will rise when its government 
announces an austerity program. If the expected costs outweigh the benefits, the market will fall. If the anticipated net effect is zero, there should be little to no market reaction.

The response of the Brazilian stock market to President Henrique Cardoso’s plan to end hyperinflation in 1994 illustrates this kind of cost-benefit analysis at work. The Cardoso government instituted fiscal consolidation, unveiled a new currency (the Real) and stopped printing money to pay its bills. In the anticipation of the Real Plan, the Brazilian stock market experienced cumulative abnormal returns of 75 percent in real dollar terms during the twelvemonth period prior to implementation. The plan worked. Over the course of the next three years Brazil went from hyperinflation to single-digit annual price increases. The permanent reduction in inflation along with other economic reforms placed the economy on a new path. The growth rate of Brazilian GDP in the two decades beginning with stabilization was 3.2 percent per yearno Asian miracle, but 1.2 percentage points faster than in the prior decade. Growth was particularly strong between 2001 and 2011—3.6 percent per year-a time during which the combination of growth and antipoverty measures lifted twenty million Brazilians out of poverty.

Unlike Brazil in the early 1990s, inflation was not the principal problem facing Chile when its policymakers implemented austerity under three successive agreements with the International Monetary Fund (IMF) between 1983 and 1989. (The Pinochet regime ended tripledigit inflation in the 1970s.) In anticipation of the future economic impact of austerity, Chile's stock market experienced negative cumulative abnormal returns in each of the twelve-month periods preceding the agreements. Across all three episodes of cold-turkey approaches to macroeconomic stabilization, the average cumulative abnormal return was negative 87 percent. In line with these negative market forecasts, real GDP also fell sharply and did not return to its pre-recession level until 1986. 
The differing reaction of the stock market to austerity programs conditional on the level of inflation is not a phenomenon exclusive to Brazil and Chile. Figure 2 demonstrates that average cumulative abnormal returns of 44 percent occurred in response to the twenty-five separate austerity programs announced in the midst of high inflation (greater than 40 percent) across twenty-one emerging nations between 1973 and 1994. Conversely, the fifty-six separate programs announced in the midst of moderate inflation (less than 40 percent) triggered average cumulative abnormal returns of negative 24 percent.

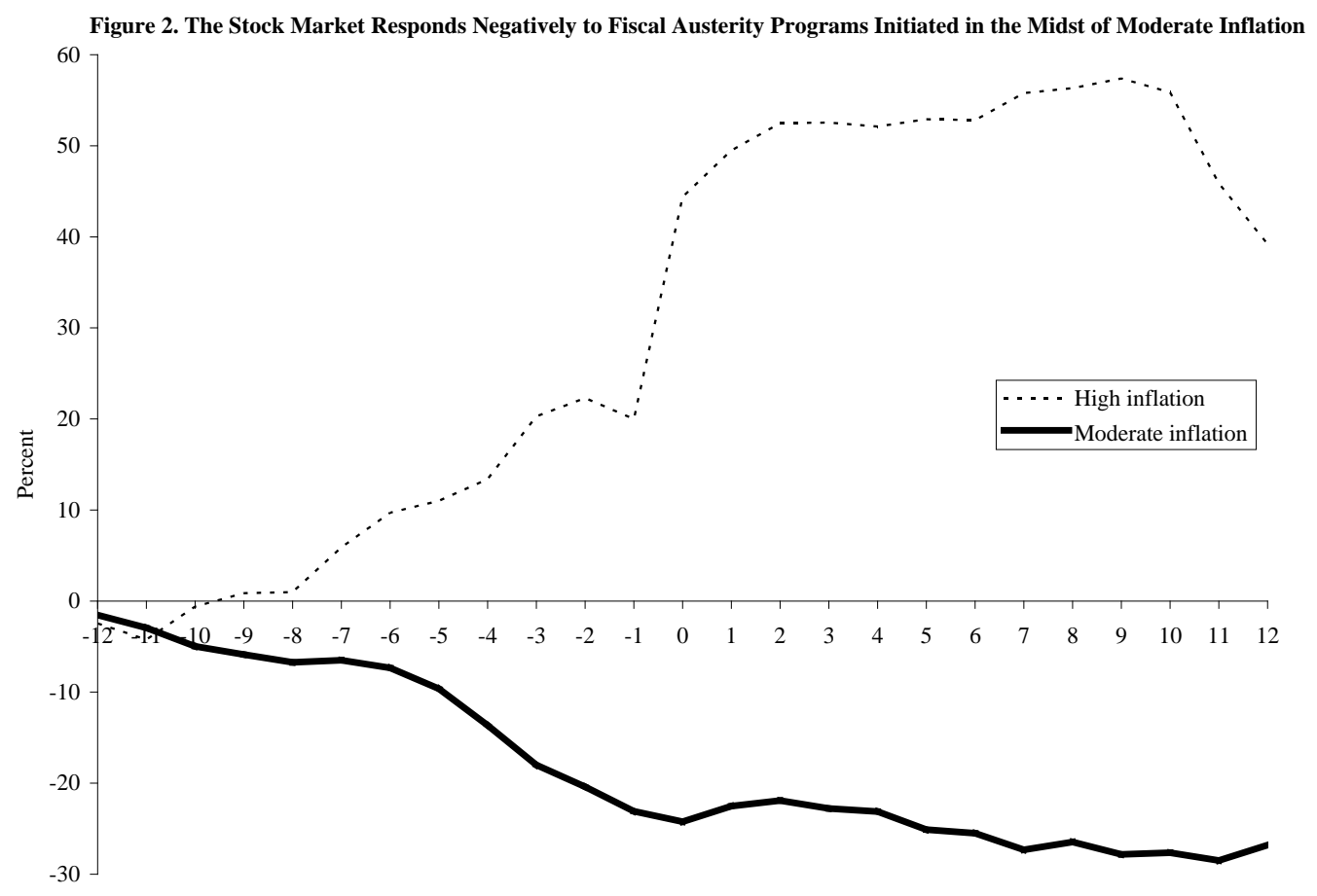

With inflation rates in the United States and the Euro Area below 2 percent in 2010, Figure 2 suggests that, rather than changing swiftly from stimulus to austerity that year, a more gradual approach to fiscal consolidation for those countries might have been optimal. Indeed, Europe's prolonged decline in economic activity in the aftermath of the Great Recession stands in contrast to the rapid recovery experienced by East Asia following its own crisis in 1997 
(caused by similar factors such as property booms and excess leverage). At least part of the difference in the post-crisis paths of employment and output in the two episodes appears to be a result of greater fiscal flexibility on the part of Asian policymakers than their European counterparts (Chari and Henry, 2014).

A gradual approach to deficit reduction need not imply a lack of seriousness—altering the speed of progress toward a specified fiscal target is not the same as abandoning it. On the contrary, gradualism can be a powerful tool in helping achieve the objectives of a broader growth strategy (Dewatripont and Roland, 1995). The goal is not to balance the budget in one fell swoop, but to implement positive net present value measures that place government debt on a sustainable trajectory.

\section{Discipline Applies to Borrowers and Lenders}

When public debt does hit crisis-inducing levels, historical data on stock-market responses in emerging markets also provide important insights about the most efficient way to address the debt overhang and insolvency that inhibit the recovery of European countries such as Greece, Ireland, Italy, Portugal, and Spain. Because there are many parallels between the economic troubles of Europe and the landscape of heavily indebted, middle-income developing countries in the late 1980s, the policy changes that resolved overhang following the Third World Debt Crisis are deeply relevant to advanced economies. A quick review of events and data demonstrates the following principle: when a government's liabilities exceed its ability to pay, discipline requires borrowers and lenders to bear the burden of adjustment in order to reach an efficient resolution. 
Following seven years of restructurings and forgone growth in the Crisis countries, and despite prior insistence that debt relief had no place in the solution, the U.S. Treasury changed tack in 1989. Then-Secretary of the Treasury Nicholas Brady unveiled a plan that called on international commercial banks to provide approximately US $\$ 65$ billion of debt forgiveness to the sixteen nations in question. The anticipation of the official announcement of a Brady deal generated average cumulative abnormal returns of 60 percent over a twelve-month preannouncement window in the stock markets of the recipient countries. It is tempting to conclude that the revaluation of assets simply reflected a transfer of wealth from bank shareholders, but additional data reject this explanation. Publicly traded U.S. commercial banks with large developing-country loan exposure experienced average cumulative abnormal returns of 35 percent during the relevant time frame.

Debt relief, however, also carries a price tag. It was given to Brady countries in exchange for their agreement to implement growth-enhancing reforms: inflation stabilization, trade liberalization, and privatization of badly run state-owned firms whose lack of profitability was a drag on public finances and helped give rise to debt overhang in the first place. Countries that instituted and sustained subsets of the reforms that were most relevant to their circumstances experienced significant improvements in economic performance. Countries that failed to honor their reform commitments (Jordan, Nigeria, and the Philippines) experienced a much smaller initial rise in the value of their stock markets than other Brady countries-30 percent versus 60 percent—and even those increases completely evaporated within a year as lack of commitment to reforms became obvious (Arslanalp and Henry, 2005).

The lesson seems clear. Reducing the debt burden can be an important part of a pragmatic growth strategy for countries that suffer from debt overhang. But debt relief will only succeed 
when implemented in concert with reforms that raise productivity and provide a business environment in which firms have an incentive to generate output, invest in capital, and hire additional workers. Resistance to writing down debts that cannot be repaid places Europe at risk for the extended malaise that has plagued Japan for two decades and stood in the way of Third World resurgence until Secretary Brady’s bold change of course.

\section{Conclusion}

As advanced and emerging nations struggle to regain their footing in the aftermath of the Great Recession, they face somewhat different challenges. Developed nations seek to return their economies to pre-crisis levels of growth and employment while responsibly addressing income inequality. Developing countries must consolidate their hard-won gains of the past several decades and implement second-stage reforms required in key areas (e.g., infrastructure and labor markets) to maintain their high rates of catch-up growth. The historical examples presented in this article provide wisdom that applies with equal relevance to the varied tasks ahead. The analytical insight at the heart of each narrative is unique, but all three stories of economic transformation contain a common truth: discipline drives turnarounds. If both advanced and developing nations internalize the lesson and embrace a disciplined approach to economic policy, they can grow in concert and create greater prosperity for all. 


\section{References}

Arslanalp, Serkan and Peter Blair Henry. 2005. “Is Debt Relief Efficient?” Journal of Finance, 60(2), 1021-1055

Chari, Anusha and Peter Blair Henry. 2014. "Two Tales of Adjustment: East Asian Lessons for European Growth.” http://www.peterblairhenry.com/wp-content/uploads/2013/11/ChariHenry-IMF-2013-Two-Tales-of-Adjustment-PRELIMINARY.pdf

Dewatripont, Mathias, and Gerard Roland. 1995. "The design of reform packages under uncertainty.” American Economic Review: 85(5) 1207-1223.

Evenett, Simon. 2013. Protectionism's Quiet Return: Global Trade Alert's Pre-G8 Summit Report Centre for Economic Policy Research, London

Henry, Peter Blair. 2002. “Is Disinflation Good for the Stock Market?” Journal of Finance, 57(4), 1617-1648.

Henry, Peter Blair. 2013. Turnaround: Third World Lessons for First World Growth. Basic Books: New York.

Krueger, Anne. 2010. “Trade Liberalization and Growth in Developing Countries,” in John Siegfried, editor, Better Living Through Economics, Harvard University press, Cambridge, MA.

Prebisch, Raul. 1950. The Economic Development of Latin America and its Principal Problems, New York: United Nations, 1950.

Singer, Hans W. 1950. "The Distribution of Gains Between Borrowing and Investing Nations," American Economic Review: 40 (2): 473-85.

\footnotetext{
* Chari: Department of Economics, University of North Carolina at Chapel Hill, Chapel Hill, NC 27599 and National Bureau of Economic Research (email: achari@unc.edu); Henry: Leonard N. Stern School of Business, New York University, New York, NY 10002 (email: peter.henry@stern.nyu.edu) and Brookings Institution. Henry gratefully acknowledges financial support from the W.R. Berkley and Richard R. West Chairs. We thank Allison Cay Parker for invaluable editorial assistance.
} 